\title{
Study on the Evaluation Index System and Standard of Arable Land Health
}

\author{
Mei Shan ${ }^{1,2, a}$, Xun Wang ${ }^{3, b}$ \\ ${ }^{1}$ College of Resources and Environment,Shandong Agricultural University,China,Shandong Taian \\ 271018 \\ ${ }^{2}$ Department of Tourism ,Taishan University,China,Shandong Taian 271000 \\ ${ }^{3}$ Taian Envionmental Protection Bureau,China,Shandong Taian 271000 \\ aemail:tigertaishan@163.com, bemail:hjbh65@126.com
}

\begin{abstract}
Keywords: Arable land health, Index system, Estimation, Standard.
Abstract. Arable land is the soul of land resources and has the core status of national food security. In this study, according to the resources(arable land natural quality and production capacity)and environment(soil environment)combined perspective, definition the concept of arable land health, explore the principles and ideas of establishing the index system of health assessment of regional arable land, put forward land health evaluation index system and evaluation standard..For the development of regional arable land health evaluation, lay the foundation for basic farmland designated to provide the basis, at the same time,put forward some problems that should be paid attention to in the application of the index system.
\end{abstract}

\section{Introduction}

Arable land is an important base for the production of modern agricultural production and human control. Quality, capacity and environment of arable land are the key factors to ensure the sustainable development of national food security and social economy（Li Qiang et al.,2010; Li Q et al.,2012) ${ }^{[1-2]}$. Arable land issues related to national food security, ecological environment quality and social stability and the rise and fall of the regime ${ }^{[3]}$, its strategic position is increasingly important. At present, foreign scholars pay more attention to the effect of land use change on the function of arable land ecosystem ${ }^{[2-3]}$. In recent years, domestic scholars began to study the service function of arable land ecosystem ${ }^{[4]}$, but there is no accepted standard and method for assessing the value of ecosystem services.

This article tries to establish a scientific evaluation index system of arable land health evaluation from the perspective of the combination of resources (natural quality and productive capacity of cultivated land) and environment (soil environment), providing reference for the delimitation of basic arable land and sustainable utilization.

\section{Origin and connotation of arable land health}

\subsection{Origin of arable land health}

The concept of "health" was first applied to medical field, which is used to describe the condition of human and other living beings. Later, due to the environmental pollution caused by human beings, a series of diseases, the concept of "health" began to be applied in Environmental Science and ecology. International Society for Ecosystem Health (ISEH) is the organization of applying health concepts to ecosystems. In the early 1940s, appeared the concept of land health.The health of the land is the land that man has used but does not function to destroy, "land organism health" refers to the ability to self renew, this ability can be diagnosed as the human health as a diagnosis. Since then on the basis of "land health" formulation, human beings put forward the concept of "ecosystem health", gradually expand and deepen the research in the field of ecology. 


\subsection{Connotation of arable land health}

There is no recognized definition of the health of arable land health. Soil health (Health soil) and land health (Health land), etc.are the related concepts. Famous land ethicists and environmental conservationist Aldo Leopold (1941) believes that the land health refers to the self renewal capacity of all biological areas. In 1943, New Zealand created the soil and health society, proposed the concept of "healthy soil - healthy people"for the first time. American scholar Doran et al. (1996) hold that the meaning of soil health and soil quality is uniform ${ }^{[5]}$. Australian scholars Pank et al. point out that soil health has a sustainable biological productivity, can promote the improvement of animal and plant health level ,maintain environmental quality ${ }^{[6-8]}$ 。

Domestic scholars Chen Meiqiu (2002) deem land health refers to a state that maintains its own normal metabolism ${ }^{[9]}$. Li Jinfeng (2009) proposed that soil health refers to the ability of the soil to maintain its ecological activity and produce healthy agricultural products ${ }^{[10]}$. Li Qiang et al. (2011) considered that the health of arable land is a comprehensive embodiment of the crop production function, ecological service function, environment maintenance function, tourism and leisure function and social security function and so on ${ }^{[11]}$.Kong Xiangbin et al (2008) believed that the health of arable land contains $1,800,000,000$ acres of the red line ${ }^{[12]}$.

Review of the above content, this study defined the concept of arable land health as: In certain areas, between life and the environment is not affected by land fertility, soil pollution, land structure, land use change, land resource constraints, the formation of a dynamic flow of energy and material cycle of the dynamic system. Arable land health represented as high soil fertility, no pollution, reasonable land structure, land use change small, land resource abundant, and the crop yield is high, etc. These factors can enough to maintain a dynamic balance of arable land ecosystem.

\section{Selection of arable land health evaluation index}

\subsection{Basic idea of arable health evaluation index selection}

The connotation of arable land health is rich. Health evaluation of arable land should be carried out from two aspects: resources and environment. From the perspective of resources, arable land health evaluation should be based on the theory of land productivity; From the perspective of environment, arable land health evaluation should be focused on soil pollution, irrigation water pollution, air pollution and other environmental indicators.

\subsection{Principles of arable health evaluation index selection}

Arable land health evaluation indicator project different relates to a number of fields and disciplines. According to the principle of scientific, comprehensive, simple, easy to use and can be set up to the actual needs to set the. Target selection to achieve two purpose: First, selected indicators can accurately reflect the quality of arable land health status; Second, make the evaluation index system as far as possible to the "handy and less", "handy" means selected index concept should be clear, "less" refers to the number of selected indicators as few as possible and easy to obtain.

\section{Index system of arable land health evaluation}

From the perspective of the combination of resources and environment. Arable land quality, arable land productivity and arable land environment index system together constitute a complete index system for comprehensive evaluation of arable land health(Table 1). Using this index system to carry out arable land health assessment, to grasp the current situation of China's arable land health in a timely manner, and to carry out a series of corresponding measures.

\subsection{Arable land quality evaluation index}

Surface soil texture excellent, tillage layer thickness, salinization degree low, high quality organic content and ground smooth, plain landform, irrigation and drainage condition is superior, plots dispersion is small compared to the arable land health good. 


\subsection{Arable land productivity evaluation index}

The higher the productivity of arable land, the better the health of the arable land. To develop agriculture and to increase food production, the key lies in policy, technology and investment. With the increase of agricultural inputs, the health status of arable land is increasing. In addition, the level of science and technology and traffic accessibility also affect the yield of arable land.The higher scientific and technological level and the traffic is accessible, the health of arable land is better.

\subsection{Arable land environmental evaluation index}

Heavy metal contaminated soil is very difficult to eliminate. If the soil heavy metals content more than a certain limit, it will become the soil pollution sources to plants, eventually through the "soil of a plant and a human body" food chain, affects the health of animals and plants and human beings. In soil heavy metals, the toxicity of arsenic and cadmium was high; the toxicity of mercury, lead and nickel was medium; the toxicity of boron, copper, manganese and zinc was very low.

Table1. Index system for arable land health evaluation

\begin{tabular}{|c|c|c|c|}
\hline $\begin{array}{l}\text { Target } \\
\text { Layer }\end{array}$ & Factor Layer & Index Layer & Factor Layer \\
\hline \multirow{6}{*}{$\begin{array}{l}\text { Arable } \\
\text { Land } \\
\text { Health }\end{array}$} & \multirow[t]{3}{*}{$\begin{array}{l}\text { Quality of } \\
\text { Arable Land }\end{array}$} & Physical Properties & $\begin{array}{l}\text { Table Soil Texture, Tillage Layer Thickness, } \\
\text { Landforms, Thickness of Barrier Layer } \\
\text { Soil Erosion Degree, Terrain, Profile } \\
\text { Configuration,Dispersion Field,Slope }\end{array}$ \\
\hline & & Chemical Properties & $\begin{array}{l}\text { Organic Matter Content, PH Value, Soil Nutrient } \\
\text { Content }\end{array}$ \\
\hline & & $\begin{array}{l}\text { Irrigation And Water } \\
\text { Conservancy } \\
\text { Facilities }\end{array}$ & Irrigation Guarantee Rate, Drainage Condition \\
\hline & \multirow[t]{2}{*}{$\begin{array}{l}\text { Arable Land } \\
\text { Productivity }\end{array}$} & Throughput & $\begin{array}{l}\text { Arable Land Area, Theoretical Capacity, Actual } \\
\text { Capacity }\end{array}$ \\
\hline & & Social Security & $\begin{array}{l}\text { Agricultural Input, Level of Science And } \\
\text { Technology, Traffic Accessibility }\end{array}$ \\
\hline & $\begin{array}{l}\text { Arable Land } \\
\text { Environment }\end{array}$ & $\begin{array}{l}\text { Soil Pollution } \\
\text { Irrigation Pollution } \\
\text { Air Pollution }\end{array}$ & $\begin{array}{l}\text { Heavy Metal (As、Cd、Cr、Cu、Hg、Pb、Zn) } \\
\text { Organic Pollutionfertilizer And Pesticide } \\
\text { Application } \\
\text { Potassium Permanganate,BOD,Ammonia } \\
\text { Nitrogen,Volatile Phenol,Cyanide,Total } \\
\text { Arsenic,Total Mercury,Total Lea,Total } \\
\text { Cadmium,Sulfur Dioxide,Nitrogen } \\
\text { Dioxide,Particulate Matter }\end{array}$ \\
\hline
\end{tabular}

\section{Standard for health evaluation of arable land}

Reference for green food production standards and requirements, according to "Environmental Quality NY/T391-2013 Green Food Production" (Ministry of Agriculture), " Arable Land Quality Acceptance Specification NY/T1120-2006 "(Ministry of Agriculture), " Types of Arable Land Area, Arable Land Classification NYT 309 - 1996" (Ministry of Agriculture), "Soil Fertility Investigation And Quality Evaluation Technology For NY/T1634-2008" (Ministry of Agriculture), "Soil Environmental Quality Standard GB15618-2008" (Environmental Protection Department), "Agricultural Soil Environmental Quality Standards (Draft)" Department of environmental protection, 2015), "High Standards of Basic Arable Land Construction Standards" (Ministry of land and resources, 2012), " Notice on Implementation of Permanent Protection of Basic Farmland" (Ministry of land and resources, Ministry of agriculture, 2009) and other relevant regulations, technical standards, achievements, etc. Based on related research, develop the land health evaluation 
criteria (Table 2). The comprehensive index method is used to evaluate the health of arable land and the results are divided into four levels: health, health, sub-health and unhealthy:

Table 2. Health evaluation standard of arable land

\begin{tabular}{|l|l|}
\hline $\begin{array}{l}\text { Arable Land } \\
\text { Health Classification } \\
\text { Arable Land Healthy }\end{array}$ & $\begin{array}{l}\text { Evaluation Criteria } \\
\text { "Body is healthy and disease". Arable land's quality is the highest and has } \\
\text { higher, stable yield, the environment is not polluted. } \\
\text { "No body disease ". Arable land's quality is higher and has higher } \\
\text { productivity, stable yield, can guarantee the arable land environment. }\end{array}$ \\
\hline $\begin{array}{l}\text { Sub Healthy Arable } \\
\text { Land }\end{array}$ & $\begin{array}{l}\text { Include three types: } \\
\text { First, "no causative agent is not strong" arable land. The environment } \\
\text { clean and no pollution, higher quality , crop yield is relatively low. Human } \\
\text { beings can relieved to eat the food produced by this type of cultivated land. } \\
\text { Second, "strong minor" arable land, crop yield and quality is high, land } \\
\text { environment is polluted by different degrees, and the soil is not clean; } \\
\text { Third, "a weak disease" arable land. The quality is low and the land } \\
\text { environment is polluted, the yield of crops is low too. } \\
\text { In view of the second, three types of arable land, the production of food } \\
\text { need to be monitored by the relevant departments to determine whether to } \\
\text { eat. }\end{array}$ \\
\hline $\begin{array}{l}\text { Include two types: } \\
\text { First,"body strong hidden serious illness" arable land.Land has high } \\
\text { quality and stable yields of crops, but the environment polluted, the } \\
\text { growth of food is not edible. } \\
\text { Second,"weak and serious illness" arable land,.The crop growth is poor, } \\
\text { low yield, poor quality, environment is polluted. }\end{array}$ \\
\hline Arable
\end{tabular}

\section{Conclusions}

5.1 The study established the evaluation index system and evaluation standard of cultivated land health.

5.2 The arable land health evaluation index system is distinct from the target layer to the index layer, and gradually refined.The arable land quality and the productivity are analyzed from the point of view of resources, arable soil environment is analyzed from the environmental point of view.

5.3 Put forward problems that should be paid attention to in the application of the index system of arable land health evaluation

\section{Reference:}

[1] QiangLi, Ye Zhao, JinmingYan. The city of agricultural land under the driving mechanism of health assessment of agricultural engineering [J]. Journal of agricultural engineering, 2010,26 (9): 301-306.

[2] QiangLi, JinmingYan. Appraising the health of agricultural land with energy analysis and fuzzy logic in the major grain re-producing region[J].CATENA,2012,99:9-17

[3] Fu Zeqiang, Cai Yunlong. Correlation analysis[J]. Journal of natural resources, change China food security and arable land resources. 2001, 16 (4): 313-319

[4]Zhixin Yang, DaweiGuan. Beijing Suburb Farmland ecosystem service function value assessment research[J]. Journal of natural resources, 2005, 20 (4):564-571. 
[5] Xiaoyu, Xie Gaodi,Ankai,Liu Chunlan,Cao Cao Cheng.North China plain wheat-corn farmland ecosystem service evaluation. Chinese Journal of eco agriculture,2011,19(2).Chinese:429-435.

[6]Li Feiyun, Fang Weiwu..Suburban Farmland ecosystem service function value assessment[J]. Shanghai rural economics,2006,(9):22-25.

[7]wei Li, Shizhong Zhang, Editor in chief. Health concept volume[M],Shanghai:Shanghai Education Press,2005.1.

[8] Doran J W,PARKIN T B.Soil health and sustainability[J].Advances in Agronomy,1996,56:2-55.

[9] PANK HURST C E HAWKE B G MCDONALD H J et al. Evaluation of soil biological properties as potential bioindicators of soil health $\mathrm{J}$ Australian Journal of Experimental Agriculture 1995,35:1015-1028

[10]Qiguo Zhao, Bo Sun, Taolin Zhang soil quality and sustainable development [M],1997, 3:113-120

[11]Tianjie Li, Keli Zhang, Soil Geography(Third Edition)[M].Beijing:Higher Education Press,2004.286-300

[12]Meiqiu Chen,Cifang Wu. Progress of land health research [Jl.Journal of Jiangxi Agricultural University,2002,24(3):324-329 